Journal of Contemporary Educational Research

Research Article

\title{
Research on the Cultivation of College Students' Design Originality from the Perspective of Cultural Confidence
}

Jinjin Chen

Shandong Women's University, Jinan 250300, Shandong Province, China

\begin{abstract}
Culture confidence is an important internal factor to promote the development of modern design in China. College students majoring in design are the mainstay of Chinese design field in the future, but some of them are lack of cultural confidence. Therefore, the school should strengthen the cultural confidence of college students majoring in design from the aspects of curriculum setting and reform, environment shaping and professional belief, so that their design originality can be stimulated and maintained, and the "Chinese original design" belonging to the new era can be created.

Key words: Cultural confidence; College students; Design originality; Cultivation path
\end{abstract}

Publication date: October, 2020

Publication online: 31 October, 2020

*Corresponding author: Jinjin Chen, chenjinjin83@163.com

College students in the new era, born in the golden period of China's development after the reform and opening up, bear an important task. Specific to the design field, the realization of "made in China" and "created in China" is a necessary condition for the rapid development of Chinese design, which inevitably requires a large number of young designers with design originality. There is no doubt that this is a new opportunity and challenge for the majority of college students majoring in design and educators engaged in the design industry.

\section{Cultural Confidence and Chinese Original Design}

Nowadays, the lack of originality in Chinese design is due to the design cultural identity and identity crisis and the lack of cultural confidence. Nowadays, information is developed and material is rich, the inheritance of Chinese traditional lifestyle, customs, moral norms and values is gradually weakening, the change of cultural identity and identity is relatively fast, and the original stable traditional cultural system has been greatly impacted ${ }^{[1]}$. Artists must realize that originality comes from tradition and their confidence in national culture, and local culture is the spiritual demand of modern people. The fundamental reason why traditional culture can nourish design originality is that it has three characteristics: scarcity, regionality and inheritance. For example, Alva Alto, known as the national architect, has taken a unique road with his works full of nationalization and humanization under the background that rationality is almost indifferent and modernist architecture is highly developed.

Creativity promotes industry and youth decides the future. Looking at the promotion of Chinese original design, it can be concluded that education is the only way to improve Chinese original design. At present, there are more than 1000 colleges and universities in China set up art and design related majors. Under the background that design education seems to be booming, the students trained under the current design education system and mode in China are usually lack of originality, humanistic feelings and social responsibility, but they have strong ability in drawing and imitating technology and skills, which is difficult to adapt to the development needs of the transformation to "created in China" ${ }^{[2]}$. The lack of cultural confidence of the 
majority of young students is the main reason for the lack of originality and the proliferation of plagiarism. The majority of students need to really establish cultural confidence and have a profound recognition and understanding of traditional culture in the value level. Only in this way can they keep the importance of culture and realize innovation in the new era.

\section{Cultivation Path of College Students' Design Originality from the Perspective of Cultural Confidence}

\subsection{Keep the classroom well and reform the curriculum}

The innovation of art seems to be the creation of the theme, content, form, technology, etc., but it still relies on the talents with innovative ability ${ }^{[3]}$. Therefore, the college students with design originality and strong cultural confidence are the future and hope of Chinese original design. At present, colleges and universities are still the main position to cultivate college students' cultural confidence, and the classroom is still the first choice. For students majoring in design, a large number of courses of traditional Chinese aesthetics should be supplemented. Teachers should give students highquality traditional Chinese art and original Chinese contemporary art. To give students guidance, inspiration and demonstration, and help them gradually identify and love Chinese art on the basis of understanding Chinese art is the inheritance goal that should be established.

In addition, as far as professional courses are concerned, it is necessary to realize that due to the vast territory in China, the economic and cultural level, national characteristics and social culture of different regions are different, so there are differences in people's aesthetic concepts and values. Schools should take these factors into full consideration when carrying out specific design education. It is necessary to analyze the local economic level, educational resources and cultural characteristics through practice, formulate educational policies that suit local conditions, and cultivate art talents suitable for local conditions. In addition, China has a broad and profound traditional culture. As a professional component of traditional culture, regional culture has always been the main source of art design. Therefore, the characteristics of art design education can be fully demonstrated by mining, sorting out and absorbing local culture in modern art and design education and giving full play to its advantages ${ }^{[4]}$. In the actual teaching, the rich forms include inviting inheritors and experts of local intangible cultural heritage to give lectures, leading students to conduct on-the-spot investigation, teachers and students to carry out relevant research or cooperation with enterprises, etc., can be carried out to enable students to have a comprehensive and rational understanding of the local cultural heritage; At the same time, teachers, as educators, should sort out the local cultural research results and bring them into the curriculum of art and design education in colleges and universities.

\subsection{Environment educates people in silence}

It is not an easy process to cultivate college students' cultural confidence and original ability. In addition to targeted training and education, it also needs the "physical environment" and "virtual environment".

From the perspective of physical environment, it includes the whole country and our campus. From the big point of view, innovation has been regarded as the soul of national progress and the inexhaustible motive force of national prosperity and development. Moreover, in the whole society, the general environment trend of ma e environment of new media, where information is spread in the form of fragmentation and liberalization. It not only brings students rich cultural resources and communication opportunities, but also breeds some problems such as the expansion of negative individualism and the entertainment of values. In terms of the construction of network culture education platform for college students, it is necessary to strengthen the supervision by using technical means objectively, and strengthen the network security awareness of college students from the perspective of subjective thinking. At the same time, the construction of the platform should start with the actual needs of college students, make use of their favorite media forms to innovate and promote the excellent traditional culture, broaden the discourse space of advanced culture, and find efficient channels for multi-directional communication, for example, widely introduce the media or new media such as culture, design APP, official account, etc., and add interactive design in it, so as to increase the interactive experience of students. In particular, the exchange and comment on the works can be designed in daily life to enhance the cultural experience of college students, so that college students have free space to play, to find the charm of culture, and to guide students to actively spread culture. 


\subsection{Professional belief and craftsman spirit}

Those colleges and universities responsible for training young designers have been given an important mission to cultivate the craftsman's spirit. These schools should pay attention to the infiltration of craftsman's spirit in students' professional learning. These schools should start from the characteristics of the design major and the professional characteristics of designers, analyze the professional quality students need to have in combination with the market demand, and cultivate craftsman's spirit from the setting of curriculum teaching links, evaluation and assessment methods, etc. As design major is an application-oriented discipline, the school should not only pay attention to the operational knowledge of skills, but also pay attention to the cultivation and training of students' professional ethics in combination with craftsman spirit and theoretical knowledge, and carry out spiritual education with the deeds of outstanding people and the development of benchmarking enterprises, so as to make students have a sense of identity, pride and awe for their profession. In addition, a large number of practical practice is necessary to cultivate students' excellent professional skills. Deepening practical teaching is a powerful measure to cultivate practical design talents with both art and skills. The exercise, learning and innovation of students in real projects and projects can not only make their theoretical knowledge tested, but also enable them to experience professional roles, cultivate their profound understanding of career and their good professional spirit in details.

In view of the fact that contemporary Chinese design needs a large number of original designers, the majority of college students majoring in design should establish cultural confidence, improve humanistic quality, understand traditional culture and advanced culture from the deep level of philosophy and values, keep the cultural gene and innovate the form. Only in this way can they create excellent works that can show Chinese spirit, Chinese value and Chinese strength.

\section{References}

[1] Li JR. Dedicating the People with Exquisite Products and Leading the Fashion with Morality [N]. Guangming Daily, March 6, 2019.

[2] Du PS, Gu JD. The concept of creation facing made in China 2025 [M]. Beijing: China Machine Press. November 2017.

[3] Ren JW, Sun XY, Liu J. On the Cultivation of College Students' Cultural Confidence in the New Era [J]. Ideological and Political Education Research, 2018 (5): 137-141.

[4] Zhao Y. Exploration and Practice on integrating Folk Arts and Crafts into Art Design Education in Colleges and Universities [J]. Art Panorama, 2015(1): 148-149. 